9-1995

\title{
Reinventing Teacher Compensation Systems
}

Carolyn Kelley

Allan Odden

Follow this and additional works at: https://repository.upenn.edu/cpre_policybriefs

Part of the Education Economics Commons, Education Policy Commons, and the Teacher Education and Professional Development Commons

\section{Recommended Citation}

Kelley, Carolyn and Odden, Allan. (1995). Reinventing Teacher Compensation Systems. CPRE Policy Briefs.

Retrieved from https://repository.upenn.edu/cpre_policybriefs/56

View on the CPRE website.

This paper is posted at ScholarlyCommons. https://repository.upenn.edu/cpre_policybriefs/56

For more information, please contact repository@pobox.upenn.edu. 


\title{
Reinventing Teacher Compensation Systems
}

\author{
Abstract \\ In this issue of CPRE Finance Briefs, the authors argue that it is now time for education to join successful \\ efforts and revise teacher pay systems. The brief provides a short history of changes in teacher \\ compensation over the last century and a discussion of key organizational and educational changes \\ today that could be reinforced by a new teacher compensation structure. It also suggests some new \\ teacher pay elements and a set of principles states and districts could follow if they embark on the \\ journey to redesign how teachers are paid. Examples of leading-edge compensation programs are \\ included in sidebars on pages 2-5.

\section{Disciplines} \\ Education Economics | Education Policy | Teacher Education and Professional Development

\section{Comments} \\ View on the CPRE website.
}




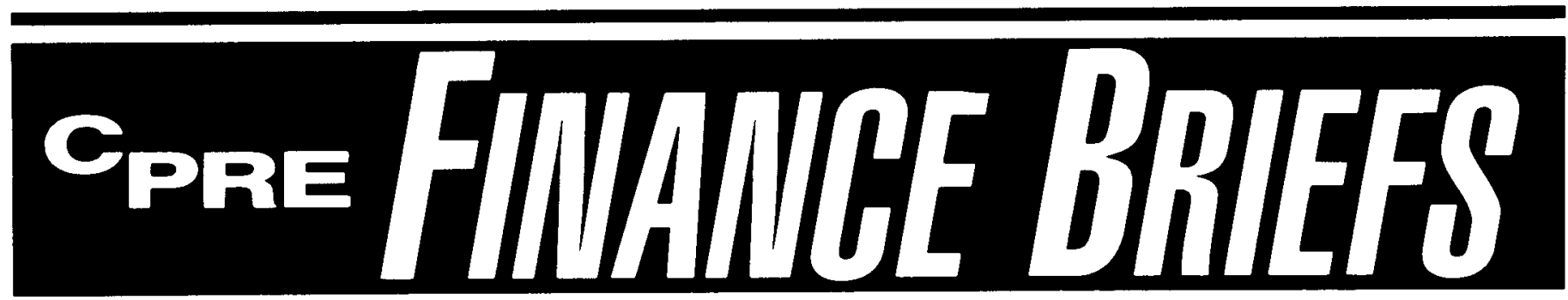

\section{Reporting on issues and research in education finance}

\section{Reinventing Teacher Compensation Systems}

\section{by Carolyn Kelley and Allan Odden}

Over the years, state and local policymakers made several well-publicized efforts to reform teacher pay. Reformers tried to use salary structures to encourage and reward good teaching. Unfortunately, these efforts largely were ineffective. As a result, teacher compensation structures today look pretty much as they did decades ago. Most districts pay teachers according to a single-salary schedule that provides salary increases for differences among teachers in education units, university degrees and years of teaching experience.

In the 1980 s, two main efforts were made to modify the single-salary schedule. Merit pay, designed to recognize and reward the best teachers, was tried in a few states and districts. And career ladder programs tried to alter the flat career structure of teaching. These efforts failed for generally the same reasons earlier efforts fizzled-they were not linked to the organizational needs and working processes of effective schools and thus were poorly designed.

For example, merit pay plans usually require individual teachers to compete against each other for a limited pool of funds. Such competition among teachers works against the collaborative culture found in most highly effective schools and thus is at odds with strategies to improve school performance.

Career ladder programs provide non-teaching jobs for a fixed number of excellent teachers, thus offering a way out of the classroom for the best professionals in schools, just the opposite of how a high-performance school should deploy its best workers. Further, teachers often were not integral partners in the design process, and too often funding was eliminated after the first years of implementation.

But other organizations in the country have been successful in implementing new compensation structures. Moreover, these new plans have been associated with wide worker acceptance, better employee morale, improved organizational performance, and higher individual salaries.

In this issue of CPRE Finance Briefs, the authors argue that it is now time for education to join these successful efforts and revise teacher pay systems. The brief provides a short history of changes in teacher compensation over the last century and a discussion of key organizational and educational changes today that could be reinforced by a new teacher compensation structure. It also suggests some new teacher pay elements and a set of principles states and districts could follow if they embark on the journey to redesign how teachers are paid. ${ }^{1}$ Examples of leading-edge compensation programs are included in sidebars on pages 2-5.

Carolyn Kelley is an assistant professor at the University of Wisconsin-Madison where she directs CPRE's Teacher Compensation Project. She also has conducted research on schoollinked services and the utility of private sector approaches to public school problems. Allan Odden is professor of education administration at the University of Wisconsin-Madison where he also serves as co-director of the Finance Center of CPRE. An expert on school finance and education policy, Dr. Odden is a prolific author.

The views expressed here are those of the authors and are not necessarily shared by CPRE or its funding agencies. 


\section{History of Teacher Pay Changes}

The history of teacher compensation provides a rich source of information on how change can "stick" when it is aligned with the strategic needs of schools and existing organizational forms (Protsik 1995). For example, in the latter half of the $1800 \mathrm{~s}$, local communities designed schools to provide basic academic skills and moral education for children. Teacher compensation consisted primarily of room and board provided by the local community. The "Boarding Round" pay system was a strong incentive for teachers to maintain positive relations with community members and to maintain a high moral character. It also reflected the barter economy of the time.

In the early $1900 \mathrm{~s}$, teacher preparation became more uniform, requiring higher levels of education, and schools began to reflect the bureaucratic organizational structures of the developing industrial cash economy. The Boarding Round system was replaced by a position-based salary system that reflected the new form of teacher work, the cash basis of the economy, and increased preservice education requirements. This system also paid elementary teachers less than secondary teachers (which in part reflected differences in education required for these positions), and unfortunately, paid women and minority teachers less than non-minority males, reflecting societal biases of the time. Nevertheless, the position-based salary schedule was a salary system aligned with the strategic aspects of the economy and school systems.

The single-salary schedule emerged early in the 20th century in response to further changes in the social and educational context. Opposition to overt discrimination and demand for greater teacher skills led to the system which paid the same salary to teachers with the same qualifications regardless of grade level taught, gender or race.

\section{Performance Awards in Kentucky}

Adopted in 1990, the Kentucky Instructional Results Information System (KIRIS) rewards schools that show improvements toward performance standards over time. Every two years, schools that exceed their improvement goals receive funds which teachers, school counselors, and the principal may distribute as they see fit. Funds may be used as salary bonuses, for professional development, or as school improvement funds. In 1994-95, the awards were about $\$ 2,000$ per teacher in eligible schools, or a total appropriation of $\$ 26$ million.

A six-part accountability index is used to measure improvements in school performance. Five parts are based on the results of reading, math, social studies, science, and writing scores on open-ended tests; a problem-solving activity; and student portfolios. The sixth component is a non-cognitive composite score based on factors such as attendance and graduation rates.

In the first year (1994-95), 38 percent of the schools received bonus awards. It is still too early to tell the long-term impact of the program, including the type of behavior it incites within each school.

The single-salary schedule did not, however, pay every teacher the same amount. Differentials were provided based on the objective measures of years of experience, educational units, and educational degrees. It paid teachers salary supplements for coaching sports, advising clubs, and coordinating activities. The bases for paying differential salary amounts were objective, measurable and not subject to administrative whim.

The single-salary schedule was appropriate for the bureaucratic, hierarchically organized school of the first half of this century. Administrators were responsible for goals, objectives and school success, and teachers were responsible mainly for delivering a basic skillsfocused, standardized curriculum. Teachers needed a beginning set of skills which were assessed in the process of licensure. Once in the system, they were paid more for each year of experience, a practice typical of bureaucracies and the way most workers were paid in the broader economy (Kelley 1995; Odden 1995).

But as the next section shows, this salary structure is not adequate for schools of today. Current reforms are requiring teachers to continuously expand their professional instructional skills, take on management and leadership roles within schools, and focus on results produced as much as services provided. A revised teacher compensation structure could help to address these new and more complex system needs.

\section{Linking Compensation to Organizational Needs}

The history of successful change in teacher compensation can serve as a guide for thinking through 
teacher compensation change today. If pay practices that endure are those that are well-aligned with broader changes in the economic and social climate, as well as the strategic needs of the school system, the obvious first step in designing a new teacher compensation structure is to identify the broader changes in the society, and parallel changes in the education system (Kelley 1995).

\section{Economic Context}

Today the broader economy is undergoing a dramatic change in the organization of the workplace and the manner in which employees are paid. The globalization of the economy is pressuring companies to drastically improve product and service quality, in a short time frame and often with limited resources. These same pressures are pressing upon governments and public agencies, including schools.

To produce these large-scale improvements, many companies are restructuring, often decentralizing their management systems and flattening their organizational structures. They are creating multi-functional work teams, giving them power and authority to accomplish organizational and team goals, while holding the teams accountable for results.

This new strategy for organizing work requires considerable ongoing investment in training. Team members are trained in technical areas, in new functional areas for which teams are responsible, and in the business skills needed to engage in self-management. Galbraith, Lawler and colleagues (1993) have termed these changes the "new logic" of organization.

Many companies following this new logic also have designed new forms of employee compensation

\section{South Carolina's Performance Pay Plan}

Established in 1984, The South Carolina School Incentive Reward Program (SIRP) is the longest running state-sponsored, group-based performance plan in the nation.

It gives performance bonuses to approximately 25 percent of schools. Schools must meet student achievement criteria to receive 80 percent of the full award for that year; an additional 10 percent is awarded to each winning school that maintains teacher and student attendance at or above 96 percent (Richards and Sheu 1992).

Schools are placed in one of five comparison bands based on percentage of students receiving free lunches; percentage receiving reducedpriced lunches; average teachers' years of education beyond the bachelor's degree; and percentage of students meeting or exceeding the readiness standard on a cognitive skills test given in all elementary schools.

Schools compete with other schools in the same band for awards, and the SIRP rewards improvement in student test scores. Awards of about $\$ 25-\$ 40$ per pupil have been distributed annually to winning schools, with the typical school receiving $\$ 15,000-\$ 20,000$. Award monies are used for instructional purposes by the winning schools.

South Carolina's banding system has been found to more equitably distribute funds across schools with different student SES levels. However, the banding system is also vulnerable to challenges of possible racial bias, since it sets lower expectations for schools serving lower SES students.

to encourage and reward the skills needed in their new organizations-team-based leadership and management skills, technical and analytical skills to support continuous improvement, and skills needed to work across traditional functional lines.

As a result, concepts such as skillsbased pay, competency-based pay, pay for knowledge, pay for professional expertise, collective rewards for adding value to performance, and gainsharing characterize new compensation strategies that have been developed and used successfully in private sector organizations (Firestone 1994; Odden and Conley 1992).

Under these strategies, individuals are not paid on the basis of seniority or for doing a particular job. They are paid based on the skills and competencies they develop to do the many job tasks they perform as work-team members. Further, a portion of each team member's pay can depend on the results of the team's effort. In short, compensation has been changed to align organizational incentives and rewards with the strategic needs of the workplace.

\section{Education Changes}

Current education reform trends reflect changes in the organization of work described above, thus suggesting a need to realign teacher compensation to these new ways of organizing schools.

Starting with the Effective Schools movement of the $1970 \mathrm{~s}$, recent reforms began requiring teachers 


\section{Douglas County, Colorado's New Pay Plan}

In 1993-94, Douglas County teachers, administrators, and community members developed a new pay plan. Implemented in 1994-95, the plan retains base pay and pay for additional coursework from the singlesalary schedule. But it revises the years of experience component to provide annual increments only for years in which teachers' performance is judged "proficient" on established criteria as judged by their principals. In addition, the new plan adds four bonuses:

1. A $\$ 1000$ bonus for outstanding teachers selected by principals who evaluate teaching practice portfolios based on specific written criteria. The number of bonuses that may be awarded in any one year, and the number of awards any one teacher may receive over time is unlimited.

2. A \$250-500 bonus for learning one or more specific skill blocks which the district identifies and provides training for. Over a threeyear period, teachers may participate voluntarily. After the three years, the skill blocks will be incorporated into the annual evaluation as skills required for all "proficient" teachers. In the first year, the district offered training for only one skill block, computer skills. The number of blocks is expected to increase over time to about seven, with the next one focused on student assessment.

3. A bonus for responsibility pay, which for most teachers is nominal (\$35-\$200 per year). Each school receives $\$ 4.50$ per student for responsibility pay. A teacher committee is established at the school site to determine how the money will be distributed. In the first year, it compensated teachers for school committee leadership, coaching, curriculum development, and for advising student activities.

4. A school-performance award bonus. Each school can voluntarily propose a school-wide project for improving student performance. Submitted at the beginning of the year to a committee of teachers and administrators, the proposal must identify planned activities and evaluation mechanisms. Bonuses are awarded to schools that successfully complete the activities, whether or not student achievement improved. This stipulation is intended to award creativity, innovation, and risk-taking. In the first year, every school participated (although a few individual teachers within the schools did not). The award per teacher depends on the number of schools and teachers that successfully complete the process.

to develop new skills and competencies and take on new roles. The Effective Schools movement required teachers to develop a set of "effective teaching" practices and to become involved with the principal in school improvement efforts. Today's education reforms expect teachers to acquire the professional expertise sufficient to teach a "world-class" curriculum well to the diverse students in schools. Today's teachers also are being asked to take broader leadership roles in school management, organization and instruction. And in the past few years, teachers also have been asked to focus on results-student achievement-rather than just education processes.

In other words, major changes in the organizational needs of schools, generally similar to those in nonschool contexts, have emerged over the past 30 years (Kelley 1995). Just as in other organizations, these changes have produced significant gaps between the needs of schools as organizations and the current teacher salary structure.

Shifting pay increments from years of experience and loosely related education units to more direct measures of professional skills and competencies, adding a mechanism that encourages ongoing training and assessment of instructional strategies, and perhaps adding group-based performance bonuses, are compensation changes that could link how teachers are paid with the evolving strategic needs of new school organizations (Conley and Odden 1995; Darling-Hammond 1996; Odden and Odden 1995; Odden 1996; Mohrman, Mohrman and Odden 1995).

\section{Elements of New Compensation Systems}

Three major elements should be considered in redesigning teacher compensation: skills- or competency-based pay, pay-at-risk, and group-based performance awards.

\section{Skills- or Competency- based Pay}

The single-salary schedule currently provides pay increases for years of experience, education units and university degrees. These variables are indirect indicators of knowledge and skills; under this system, a teacher with more education units and more experience in the classroom is assumed to have developed a greater professional expertise. Furthermore, many of the credits used as bases for salary increases 
are only loosely-if at all-con nected to teaching responsibilities or to emerging notions of challenging subject-matter instruction.

A skills- or competency-based pay system would more directly measure teacher knowledge and skills. Such a system could reward the development of three types of knowledge and skills. The first, and most critical, would be depth in the areas of content, curriculum and instructional expertise. A second set of skills would be "breadth" skills-those vital to important non-teaching functions such as curriculum development, professional development, guidance counseling, and parent outreach. A third set would be "management" skills, particularly for schools engaged in site-based management.

A skills/competency-based pay salary component could be added to the current salary schedule, replace either the education or experience component of the current salary schedule, or replace both components (see Models 1-4 on pages $6,7,8$, and 9 for examples of salary schedules incorporating elements of skills-based pay).

For example, salary increases could be tied to professional licensure and certification such as that being developed by the Interstate New Teacher Assessment and Support Consortium (see INTASC, 1995), the Educational Testing Service's PRAXIS, and the National Board for Professional Teaching Standards. Teachers could start their teaching career with a provisional license (a temporary teaching permit) at a beginning salary level, and earn significant bumps in pay when they receive a professional teaching license, and if they become certified by the National Board for Professional Teaching Standards.

\section{School-Based Rewards in Dallas, Texas}

The Dallas school-based performance award is part of the district's accountability system, created by a 1990 Commission with substantial business community involvement. The performance measure is primarily based on the results of the Texas Assessment of Academic Skills, and the Iowa Test of Basic Skills, with weights for each that vary annually.

The award is based on gain scores, aggregated to the school level from individual student data. Through complex two-stage regression analysis, the predicted score is purged of the influence of socio-economic variables including race, ethnicity, English proficiency, school mobility, poverty status, and school overcrowding. These achievement gains are supplemented by school-wide measures of student attendance, grade-to-grade promotion, drop-out rates, enrollments in accelerated courses, and SAT and PSAT scores.

Schools' final performance gain scores are then ranked from highest to lowest. Each winning school receives $\$ 2,000$, its principal and teachers receive a bonus of $\$ 1,000$, and the nonprofessional staff receive $\$ 500$ each from a fixed pot of money. Awards are provided to staffs and schools by rank order, until the budgeted amount is expended. In 1994-95, Dallas created a second tier of winners, with bonuses of $\$ 450$ for the professionals and $\$ 225$ for the nonprofessional staff, to provide incentives to the lower ranked but still improving schools.

A local or national skills-assessment system driven by the teaching profession could identify and assess additional milestones between professional licensure and Board certification. Locally determined salary increases could be linked to these accomplishments.

Skills-based pay should be clearly distinguished from individual performance-based pay systems which traditionally have evaluated teachers against one another for a fixed pool of funds. Individual performance systems usually aim to identify and reward the "best" teachers with additional pay. In contrast, skills-based pay rewards teachers for attaining and being able to use knowledge and competencies valued by the schoolsuch as the ability to teach all students the mathematics promoted by the National Council of Teachers of Mathematics. Skill attainment is judged against a predetermined, clear-cut standard. It does not create competition among teachers, but signals the type of skills the school wants its faculty to acquire. Skills-based pay systems, thus, focus individual skill development on the knowledge and skills necessary for the organization to accomplish its goals.

\section{Pay-At-Risk}

Some organizations require employees to put a portion of base pay "at-risk" until key sales or financial targets are met. This notion of pay-at-risk does not fit education. But at General Motors' new Saturn plant in Tennessee, employees have 10 percent of their base pay at-risk in ways that may apply to education. Five percent of pay is contingent upon all workers spending at least 5 percent of the work year (92 hours) 
in ongoing training that is provided by the plant. Another 5 percent is contingent on the plant meeting certain quality and production targets for its cars.

The idea of committing teachers, schools and school systems to an ongoing training process as well as to meeting high quality standards could have appeal in education. Thus, a percentage of teachers' base pay could be contingent upon each teacher engaging in a specified amount of professional development each year, such as 100 hours. The district or school would have to provide professional development opportunities and the teacher would have a strong incentive to participate. Such training could focus primarily on development of the various competencies in a skillsbased pay structure. Careful thought would need to go into the design and implementation of the professional development activities to be sure they are effective and support the student learning goals of the school and district.

The quality concept could be transferred in many ways to education. One way would be to require the faculty to work together to produce a performance report, such as the School Quality Review in New York State. The report would provide a vehicle for faculty to develop reflective practice, and for them to take part in an ongoing process of improving both teaching skills and the educational program.
In short, states or districts could put a portion of teacher pay atrisk, with some percentage contingent upon engaging in ongoing professional development and the remainder contingent on producing a focused, useful, quality performance report which assesses the educational strategies of the school in light of student achievement targets.

\section{Group-based Performance Awards}

Group-based performance awards, or collective incentive-pay plans, recognize that student outcomes are the joint product of many teachers working together in a school. They explicitly encourage school staff to work together toward common goals-such as

\begin{tabular}{|c|c|c|c|c|c|c|}
\hline \multicolumn{7}{|c|}{$\begin{array}{c}\text { MODEL 1 } \\
\text { Current Step and Column Salary Schedule with } \\
\text { Skills-Based Pay Additions (professionally and locally assessed) }\end{array}$} \\
\hline Experience & $\underset{\text { BA }}{\text { Column } 1}$ & $\begin{array}{c}\text { Column } 2 \\
\text { BA }+\end{array}$ & $\underset{\text { MA }}{\text { Column } 3}$ & $\begin{array}{c}\text { Column } 4 \\
\text { MA+ }\end{array}$ & $\begin{array}{l}\text { Skills-Based Pay } \\
\text { Increments } \\
\text { (professionally } \\
\text { assessed) }\end{array}$ & \begin{tabular}{|l} 
Skills-Based Pay \\
Increments \\
(examples) \\
(locally assessed)
\end{tabular} \\
\hline Step 1 & & & & & $\begin{array}{l}\text { Passing a Content } \\
\text { Test in Area of } \\
\text { License }\end{array}$ & $\begin{array}{c}\text { Non-graded } \\
\text { Primary School }\end{array}$ \\
\hline Step 2 & & & & & $\begin{array}{l}\text { Licensure in a } \\
\text { Second Area }\end{array}$ & $\begin{array}{l}\text { Cooperative } \\
\text { Learning }\end{array}$ \\
\hline Step 3 & & & & & $\begin{array}{l}\text { Licensure in a } \\
\text { Shortage Area }\end{array}$ & $\begin{array}{c}\text { Reading } \\
\text { Recovery }\end{array}$ \\
\hline Step 4 & & & & & $\begin{array}{l}\text { Certification from } \\
\text { National Board for } \\
\text { Professional } \\
\text { Teaching Standards }\end{array}$ & Computer Skills \\
\hline \multicolumn{7}{|l|}{ Step 5} \\
\hline \multicolumn{7}{|l|}{ Step 6} \\
\hline \multicolumn{7}{|l|}{ Step 7} \\
\hline \multicolumn{7}{|l|}{ Step 8} \\
\hline Step $\mathrm{n}$ & & & & & & \\
\hline
\end{tabular}

Model 1 maintains the current single-salary schedule structure, with annual increments for years of experience (steps) and additional educational units (columns). It adds to this structure salary increments for skills demonstrated through professional assessment procedures, and for skills identified and assessed locally by the school or district. Local districts could determine the degree to which educational units (columns) would need to be related to areas of licensure and local educational needs. Currently, some locals and states make these requirements; others do not. Specific dollar amounts would be identified for each cell in this model. 
improving student performance. Collective incentives provide an important symbolic focus on outcomes while avoiding the divisive aspects of individual performance incentives.

Individual merit pay, the most commonly applied outcome-oriented incentive system in education, creates competitive rather than collegial work environments. In addition, the underlying assumption of individual merit pay is that the individual teacher has control over the achievement of school goals. By contrast, collective incentives, such as groupbased performance awards, assume the entire faculty and students must work together to produce student performance and, thus, provide to everyone in a school a salary bonus for achieving collective goals.

Group-based performance incentives could provide bonuses to all school employees or to teams of teachers, and additional funds for the school when, for example, student achievement in core content areas exceeded some predetermined criterion for improvement.

Gainsharing is another type of group-based performance incentive. Gainsharing programs provide incentives for employees to find more efficient means of achieving organizational goals. For example, school faculties that found lower-cost means of providing the same quality services could receive a portion of the cost-savings, with the rest of the funds going toward instructional materials.

Group-based performance awards would need to be carefully designed. They would need to be based on improvements in performance. They also would need to be adjusted for student mobility, be explicit about the achievement targets for students in special education programs, capture student performance across the full range in order not to ignore the bottom half, and include appropriate modifications for socio-economic background, to insure a level playing field for participation in the award.

MODEL 2

\section{Performance Reviews for Annual Increments Combined with Skills-based Pay Elements}

\begin{tabular}{|c|c|c|}
\hline Annual Performance Reviews & $\begin{array}{c}\text { Additional Local } \\
\text { Skills/Competencies }\end{array}$ & \\
\hline Performance Review 1 & Skill Area A & \\
\hline Performance Review 2 & Skill Area B & \multirow{3}{*}{$\begin{array}{l}\text { Certification from National } \\
\text { Board for Professional } \\
\text { Teaching Standards: } 5-10 \\
\text { percent salary addition over } \\
\text { base salary from both Columns } \\
1 \text { and } 2 \text { but only after } \\
\text { Performance Review at some } \\
\text { step, e.g., Step 4. }\end{array}$} \\
\hline Performance Review 3 & Skill Area C & \\
\hline Performance Review 4 & Skill Area D & \\
\hline Performance Review 5 & Skill Area E & \\
\hline Performance Review 6 & Skill Area $\mathrm{F}$ & \\
\hline Performance Review 7 & & \\
\hline Performance Review 8 & & \\
\hline Performance Review 9 & & \\
\hline Performance Review 10 & & \\
\hline
\end{tabular}

Model 2 modifies the current single-salary schedule by providing annual salary increments (steps) only for those teachers who have successfully passed a performance review, ideally, conducted through a professional, peer-review process. Teachers would also receive pay increments for demonstrating skills and competencies identified by the local school or district as those needed to achieve student achievement goals. The specified skills could be learned in a variety of ways (such as through coursework, staff development, individual research, or professional networking opportunities), and would replace the educational units in the traditional single-salary schedule. In addition, teachers who achieved certification from the National Board for Professional Teaching Standards would receive a 5-10 percent pay increase. Specific dollar amounts would need to be identified for each cell in this model. 


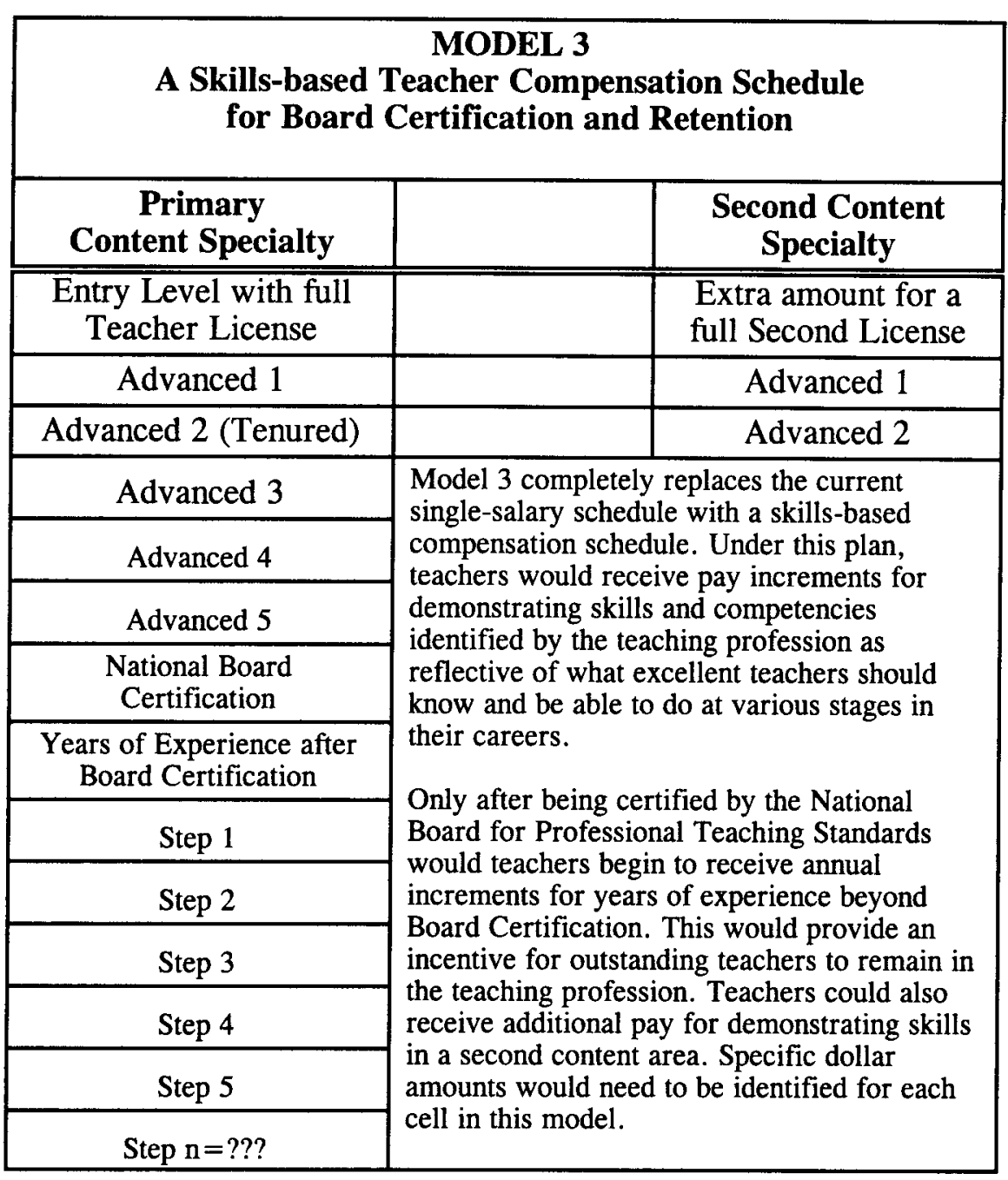

\section{Design and Development}

Generally, notions of skills- or competency-based pay, pay-atrisk, and group-based performance awards are new to schools and education systems. However, several states and districts are attempting to better align their compensation systems with current educational goals and the organization of schools.

Kentucky, South Carolina, and Texas have developed schoolbased performance awards for improvements in student performance over time. Douglas County, Colorado; Rochester, New York; Boston, Massachusetts; and Dallas, Texas are districts that pensation systems, incorporating principles of skills-based pay, individual-, group-, and schoolbased performance awards, and job-based pay. Further, a growing number of districts have agreed to reward teachers for participating in or successfully completing the National Board certification process. Early results suggest that these efforts have the potential to support teacher professional development and encourage teachers to focus on improving student achievement. (Programs in Kentucky, South Carolina, Douglas County, and Dallas are described briefly in the sidebars on pages 2 , 3,4 , and 5.)

In contrast to education, other enterprises have been using these forms of pay for several years and their early experiences provide some lessons that may be applicable to education. Interestingly, studies show that the process issues are even more crucial than the technical issues (Jenkins, et al. 1992).

\section{Process Principles}

Ten key process principles are important to the successful development, design, and implementation of a new compensation system that incorporates any or all of the elements of skills-based pay, payat-risk, or group-based performance rewards.

1. Involvement of all key parties, and especially those whose compensation is being affected, is the preeminent principle for successfully changing compensation policies. Teacher unions, administrators, school boards and the public all should be centrally involved in the process of development, design and implementation.

\section{Broad agreement on the most} valued educational results is also crucial. All parties-teachers, administrators, board members, parents and the public-need to agree on the results that are most valued.

\section{Sound, comprehensive evalu-} ation systems need to be in place to assess teacher knowledge and skill development in a skills-based pay system, and to evaluate organizational products and processes to be rewarded through group-based performance awards. Assessment mechanisms might include measures of student achievement, parent satisfaction, and teacher and administrator skills, knowledge, and performance.

4. Adequate funding which is integrated within the school finance structure is less likely to be vulnerable to cuts than a 
separate funding pool. Lack of funding and a lack of a long-term funding commitment have been key aspects of the downfall of many efforts to reform compensation in education. Transition funds often are needed to move from the old to the new structure, and performance bonuses need a stable funding pool.

\section{Investments in ongoing pro-} fessional development are key to skills- and competency-based pay structures. Such investments should be in the range of 2-3 percent of the operating budget.

\section{Quotas should be avoided. All} schools meeting performanceimprovement targets should be rewarded, not just a fixed percent- age of schools. Organizational excellence is dependent on consistent rewards for improvements in performance.

\section{General conditions of work} must be addressed. The better the conditions of work in a school (teacher involvement in decisionmaking, sound facilities, availability of materials, safety, etc.), the more likely a new form of compensation can be implemented successfully. A corollary to this principle is that the compensation system should be designed with the general conditions of work in mind. For example, skills assessment in a high-involvement school should incorporate teachers fully in the assessment process.
8. Management maturity is also important. Administrators and the school board should have good working relations, and the administration should develop a history of working cooperatively with teachers and their unions to further system goals and objectives. Restructuring the salary schedule should occur in an environment characterized by interest-based bargaining, in which each party recognizes the interests and concerns of the other parties.

9. Labor maturity goes hand-inhand with the behavior of the administration. Teacher associations, and their members, need to have positive commitment to the academic goals of the school, good working relations among

\section{MODEL 4}

\section{A Comprehensive Skills-Based Teacher Compensation Schedule High School Version}

\begin{tabular}{|c|c|c|c|c|}
\hline $\begin{array}{c}\text { First Content } \\
\text { Specialty }\end{array}$ & $\begin{array}{c}\text { Second Content } \\
\text { Specialty }\end{array}$ & $\begin{array}{c}\text { School-Site Expertise } \\
\text { (examples) }\end{array}$ & Breadth Skills & $\begin{array}{c}\begin{array}{c}\text { Management } \\
\text { Skills }\end{array} \\
\end{array}$ \\
\hline Entry & & Spanish Fluency & Counseling & $\begin{array}{c}\text { Decision- } \\
\text { Making Team } \\
\text { Leader }\end{array}$ \\
\hline Provisional License & Provisional License & Hmong Fluency & $\begin{array}{l}\text { Professional } \\
\text { Development }\end{array}$ & $\begin{array}{c}\text { School } \\
\text { Operations }\end{array}$ \\
\hline Professional License & Professional License & & & \\
\hline Advanced 1 & Advanced 1 & Korean Fluency & $\begin{array}{c}\text { Curriculum } \\
\text { Development }\end{array}$ & Budgeting \\
\hline $\begin{array}{l}\text { Advanced } 2 \\
\text { (Tenure?) }\end{array}$ & $\begin{array}{l}\text { Advanced } 2 \\
\text { ('Tenure?) }\end{array}$ & Reading Recovery & $\begin{array}{l}\text { School to Work } \\
\text { Transition }\end{array}$ & $\begin{array}{c}\text { Accounting } \\
\text { and Financial } \\
\mathrm{Mgt}\end{array}$ \\
\hline $\begin{array}{c}\text { Advanced 3 } \\
\text { (Recertification?) }\end{array}$ & & & $\begin{array}{l}\text { Computers and } \\
\text { Technology }\end{array}$ & Marketing \\
\hline Advanced 4 & & & $\begin{array}{l}\text { Community } \\
\text { Outreach }\end{array}$ & $\begin{array}{l}\text { Program } \\
\text { Evaluation }\end{array}$ \\
\hline Advanced 5 & & & Family Liaison & \\
\hline $\begin{array}{l}\text { National Board } \\
\text { Certification }\end{array}$ & & & & \\
\hline
\end{tabular}

Model 4 builds on Model 3, but adds opportunities for teachers to receive pay increments for demonstrating skills and competencies identified by the school or district as important for achieving local educational goals. This model provides for tailoring of teacher skill development to needs of the local school context, including specific depth and breadth skills geared to the local student population, and management skills which may be required for local school operations. Specific dollar amounts would need to be identified for each cell in this model. 
themselves, and a tradition of working with management toward education system key goals.

10. Persistence until the plan is "perfected" is the key to longterm success. Most plans have initial "bugs" and are viewed with skepticism by some employees. Thus, persistence is needed to continue implementation, to revise the plan when problems are identified, and to encourage full participation to see how the plan works when fully implemented.

\section{Technical Principles}

Although there are numerous technical design issues, any new compensation system must first be perceived as fair by everyone involved. The system must also be communicated in a way that can be clearly understood by all those affected. And the new system must provide incentives that will lead to the desired teacher behaviors such as working collegially in schools, actively learning new skills and competencies, and seeking to improve learning among all students. In addition, there are specific design issues associated with each type of compensation.

\section{Skills- and competency-based} plans should include:

- clear, specific and measurable skill blocks. Skill blocks should be directly related to the needs of a particular school or district and provided in written form with clear standards. They could be designed locally or could be based on national standards developed by subject-matter associations.

- an objective, sound, and credible assessment system that involves teachers and administrators. In the long term, core curriculum and instruction skill blocks should probably be assessed by a state or national teaching standards board, as is done in many other professions (Kelley and Taylor 1995).

Pay-at-risk plans should include:

- identification of tasks critical to a district's top education goals; and

- selection of one to two tasks that both teachers and the district can readily implement, such as ongoing training and an ongoing quality review.

Performance awards plans should:

- be given on a group basis, not based on individual performance. Usually this means everyone in a school-professional and classified staff-would be eligible.

- clearly state what performance is most valued-such as student achievement, student/teacher attendance, and parent satisfaction. The system will get more of what is in the performance measure and less of other system results. Thus, if the system focuses on achievement, it should incorporate a full range of achievement measures, over a range of subject areas.

- be given based on improvements over some historic base, should reflect local context, and should set timetables for reaching goals. The performance assessment should also recognize changes in the student population, such as student mobility, which may impede accurate measures of progress.

- be funded at levels that reward all schools meeting performance targets. Stability in performance award funding is essential for the awards to serve as an incentive for future performance improvements.
- provide rewards that are valued by teachers. Such awards could be salary bonuses, or dollars for school improvement activities or professional development.

Performance-based plans should also give teachers professional control over the work environment. If teachers are to be held responsible for student results, they need to have the capacity to improve organizational effectiveness. Knowledge, power, and information should be devolved to teachers to give them the capacity to make the changes needed to create performance improvements (Wohlstetter and Mohrman 1994).

\section{New Structures and Approaches to Compensation}

No one compensation plan should be viewed as an ideal, or universally applicable model. And teacher compensation systems alone are not the solution to vague and often conflicting educational goals, and low levels of student achievement. However, compensation is a potentially powerful tool that could be used to support education reform efforts, reward excellence, and undergird a climate of educational excellence. The compensation reforms in Kentucky, South Carolina, Dallas, and Douglas County, as well as research evidence from the private sector provide some early lessons, about new approaches to teacher compensation.

State and local policymakers may want to consider launching efforts to transform compensation by adding elements of skills- or competency-based pay. This would send a signal to teachers and the education system that new skills are needed and valued, and that a key to accomplishing the educa- 
tion goal of teaching students to world-class achievement levels is to enhance the professional knowledge and skills of teachers. Payat-risk and performance bonuses should also be considered, but probably as smaller elements of new compensation programs.

\section{References}

Conley, S., and Odden, A. R. (1995). "Linking teacher compensation to teacher career development: A strategic examination." Educational Evaluation and Policy Analysis 17(2), 219238.

Darling-Hammond, L. (1996, forthcoming). "Beyond bureaucracy: creating incentives for 'high performance' schools." In S. Fuhrman and J. O'Day, Eds. Incentives and Systemic Reform. San Francisco: Jossey-Bass.

Firestone, W. A. (1994). "Redesigning teacher salary systems for education reform." American Educational Research Journal, 31(3), pp. 549-574.

Galbraith, J. R., Lawler, E. E., and Associates. (1993). Organizing for the Future: The New Logic for Managing Complexity. San Francisco: Jossey-Bass.

Interstate New Teacher Assessment and Support Consortium. (1995). The INTASC Performance Assessment Development Project, Draft. Washington, DC.: Council of Chief State School Officers.

Jenkins, G. D. , Ledford, G. E., Jr., Gupta, N., and Doty, D. H. (1992). Skill-based Pay: Practices, Payoffs, Pitfalls, and Prescriptions. Scottsdale, AZ: American Compensation Assn.

Kelley, C. (1995). "Teacher compensation and organization." Consortium for Policy Research in Education, University of Wisconsin-Madison.
Kelley, C., and Taylor, C. (1995). "Compensation and skill development in four professions and implications for the teaching profession." Consortium for Policy Research in Education, University of Wisconsin-Madison.

Lawler, E. E., III (1990). Strategic Pay. San Francisco: Jossey-Bass.

Mohrman, A. M., Jr., Mohrman, S. A., and Odden, A. R. (1995, forthcoming). "Aligning teacher compensation with systemic school reform: Skill-based pay and group-based performance pay." Educational Evaluation and Policy Analysis.

National Board for Professional Teaching Standards. (1994). What Teachers Should Know and Be Able to Do. Detroit, MI: Author.

Odden, A. R. (1996, forthcoming). "Incentives, school organization and teacher compensation." In S. Fuhrman, and J. O'Day (Eds.), Incentives and Systemic Reform. San Francisco: Jossey-Bass.

Odden, A. R., and Conley, S. (1992). "Restructuring teacher compensation systems." In A. Odden (Ed.), Rethinking School Finance: An Agenda for the 1990's (pp. 41-96). San Francisco: Jossey-Bass.

Odden, A. R., and Odden, E. R. (1995). Educational Leadership for America's Schools. New York: McGraw-Hill.
Protsik, J. (1995). "History of teacher pay and incentive reforms." Consortium for Policy Research in Education, University of Wisconsin-Madison.

Richards, C. E., and Sheu, T. M. (1992). "The South Carolina school incentive reward program: A policy analysis." Economics of Education Review, 11:7186.

Wohlstetter, P., and S. A. Mohrman. (1994). "School-based management: Promise and process." CPRE Finance Briefs. New Brunswick, NJ: Eagleton Institute of Politics, Consortium for Policy Research in Education.

\section{Endnote}

1.The CPRE Finance Center's research on teacher compensation has been informed by a series of meetings held with leaders from several key education organizations, supported in part by the Pew Charitable Trusts. We would like to thank the Teacher Compensation Working Group for their insightful comments. The opinions expressed in this paper are those of the authors, and do not necessarily reflect the opinions of the members of the Teacher Compensation Working Group, CPRE, or the Pew Charitable Trusts.

\section{New CPRE-Sponsored Book Available Soon}

\section{Incentives in Systemic Reform}

edited by Susan H. Fuhrman and Jennifer O'Day

Available Spring 1996 from Jossey-Bass, San Francisco, CA (415) 433-1740

Some of today's top policy analysts discuss issues such as teacher incentives and student performance, student incentives, standards and instructional reform, and going to scale with education reforms. 